\title{
Analisis Keberlanjutan Usaha Mikrokecil Dan Menengah Menjalani New Normal Saat Pandemi Corona Desa Banjarsari Kec. Cerme Kabupaten Gresik
}

\author{
Moh Afrizal Miradji ${ }^{1}$, Martha Suhardiyah ${ }^{2}$, Bayu Rama Laksono ${ }^{3}$, Sigit Prihanto Utomo ${ }^{4}$ \\ ,Sutama Wisnu Dyatmika \\ 1,2,3,4 Program Studi Akuntansi, Fakultas Ekonomi, Universitas PGRI Adi Buana Surabaya \\ ${ }^{5}$ Program Studi Manajemen, Fakultas Ekonomi, Universitas PGRI Adi Buana Surabaya \\ e-mail koresponden: afrizal@unipasby.ac.id
}

\begin{abstract}
ABSTRAK
Pandemi Covid 19 yang telah melanda berbagai negara mengakibatkan beberapa dampak permasalahan keuangan khususnya bagi pelaku usaha. Pemerintah telah melakukan berbagai upaya agar pelaku usaha kecil menengah tetap bertahan menghadapi tatanan kehidupan baru covid 19, salah satunya dengan memmberikan relaksasi pajak dan kredit. Pelaku usaha memiliki tantangan besar dalam menghadapi tatanan kehidupan baru covid 19. Hal yang bisa dilakukan oleh pelaku usaha yaitu dengan melakukan evaluasi mengenai kinerja usahanya melalui analisis laporan keuangan. Laporan arus kas ini merupakan laporan yang memberikan informasi mengenai arus kas masuk dan arus kas keluar dari sebuah usaha dalam periode tertentu. Laporan arus kas dapat memberikan informasi mengenai kemampuan usaha dalam menghasilkan kas dari kegiatan operasi, mempertahankan serta meningkatkan kapasitas operasi dan kemampuan memeuhi kewajiban keuangan. Laporan arus kas ini bermanfaat bagi pelaku UMKM untuk mengevaluasi kegiatan oeprasi selama periode tertentu dan membantu pemilik usaha untuk membuat perencanaan aktivitas pendanaan dan investasi di masa mendatang. Berdasarkan pada permasalahan tersebut maka tim melalui kemitraan antara akademisi dan pelaku UMKM melakukan penyulukan mengenai pengetahuan pengelolaan anggaran (manajemen keuangan) melalui penyusunan laporan arus kas. Kegiatan ini dilakukan dengan harapan pelaku UMKM dapat bertahan di tatanan kehidupan baru Covid-19.
\end{abstract}

Kata Kunci: Pengelolaan anggaran, Laporan Keuangan, Pengambilan Keputusan

\begin{abstract}
The Covid 19 pandemic that has hit various countries has resulted in several impacts of financial problems, especially for business actors. The government has made various efforts so that small and medium businesses can survive the new life order of Covid 19, one of which is by providing tax and credit relaxation. Business actors have big challenges in facing the new life order of Covid 19. What business actors can do is to evaluate their business performance through financial statement analysis. This cash flow statement is a report that provides information about cash inflows and cash outflows from a business in a certain period. Cash flow statements can provide information about the ability of a business to generate cash from operating activities, maintain and increase operating capacity and the ability to meet financial obligations. This cash flow statement is useful for MSMEs to evaluate operation activities during a certain period and helps business owners to plan future investment and financing activities. Based on these problems, the team, through a partnership between academics and
\end{abstract}


EKOBIS ABDIMAS

Jurnal Pengabdian Masyarakat
Volume 1, Nomor 2, Desember, 2020

E - ISSN : 2721-9933

UMKM players, conducted counseling on budget management knowledge (financial management) through the preparation of cash flow reports. This activity was carried out with the hope that MSME players could survive the new life order of Covid-19.

Keywords: Budget management, financial reports, decision making 


\section{PENDAHULUAN}

Dunia kini sedang menghadapi krisis akibat pandemi Covid-19. Di Indonesia, krisis tersebut berdampak besar terhadap pelaku usaha, yang 99 persen adalah usaha mikro, kecil dan menengah (UMKM). Menteri Koperasi dan UKM Teten Masduki mengatakan, pemerintah akan memprioritaskan kebijakan bagi sektor UMKM dalam pembangunan ekonomi nasional. Pemerintah telah merumuskan 5 langkah kebijakan untuk menyelesaikan permasalahan UMKM yang terpuruk di tengah pandemi.Pertama, mendorong 98 persen pelaku usaha mikro dan ultra mikro untuk masuk ke dalam kelompok miskin baru. Kedua, penundaan cicilan dan bunganya hingga 6 bulan, karena sebagian besar UMKM mengalami masalah keuangan. Ketiga, pembiayaan UMKM dan koperasi melalui Kredit Usaha Rakyat (KUR). Keempat adalah mendorong agar belanja pemerintah diprioritaskan bagi produk UMKM. Kelima, UMKM harus berinovasi dan beradaptasi dengan market baru. (Kemenkop 2020)

Pemerintah terus berupaya untuk memberikan perlindungan dan pemulihan UMKM, melalui program relaksasi pajak dan kredit. Akan tetapi UMKM juga harus melakukan pembatasan pengeluaran dan evaluasi keuangan secara rutin untuk tetap bertahan selama pandemi. Hal-hal yang bisa dilakukan oleh pelaku UMKM yaitu evaluasi ketersediaan kas (manajemen arus kas), perkiraan penjualan, belanja modal dan lain-lain. Pelaku UMKM harus menyiapkan strategi agar dapat bertahan dari pandemi Covid-19. Strategi yang dapat dilakukan antara lain penawaran bisnis (memberikan bonus, promo, diskon), tidak meningkatkan volume produksi serta persediaan, menciptakan sumber pendapatan baru melalui produk yang sedang diminati, efisiensi biaya pemasaran dengan memanfaatkan platform online gratis (sosial media), pengurangan pembayaran gaji karyawan, mengevaluasi rencana belanja melalui manajemen arus kas.

Perekonomian masyarakat Desa Banjarsari menggantungan hidupnya dari faktor pertanian baik pertanian sawah seperti padi tebu dan jagung, hingga pertanian non sawah seperti tambak, kolam budidaya dan kebun buah - buahan. Sumber penghasilan masyarakat Desa Banjasari yang paling mendominasi adalah hasil perikanan, sehingga banyak pelaku UMKM yang bergerak di bidang perikanan seperti tambak bandeng dan beberapa kolam budidaya udang .

Berdasarkan hasil wawancara yang dilakukan oleh tim, ditemukan bahwa pelaku UMKM di Desa Banjasari Kecamatan Cerme Kabupaten Gresik tidak melakukan pengelolaan keuangan dengan baik dan kurangnya pengetahuan terkait dengan manajemen keuangan (manajemen arus kas). Usaha Mikro Kecil Menengah (UMKM) berperan penting dalam mendorong pemerataan kesejahteraan masyarakat dan menjadi tulang punggung perekonomian Indonesia. (Vera et al, 2018). Pengelolaan keuangan yang dilakukan secara transparan dan akurat dapat membantu pelaku UMKM melakukan evaluasi kinerja usaha untuk mempertahankan kelangsungan usahanya. Pengelolaan keuangan sering kali menjadi permasalahan utama UMKM. Kontribusi dan peran UMKM di Indonesia yang strategis ternyata masih dihadapkan pada berbagai 
permasalahan Santi, Pramestika Era (2017)

Keberadaan UMKM terbukti mampu menjadi penyelamat perekonomian, khususnya di Indonesia. Sektor UMKM menyerap 97.22\% tenaga kerja dari pelaku usaha nasional. Kontribusi yang diberikan UMKM diharapkan akan berlanjut dengan cara pemerintah dan pihak-pihak yang terkait memiliki acuan yang jelas mengenai faktor-faktor yang mempengaruhi keberhasilan usaha (Kemenperin 2016). Perkembangan dunia usaha yang semakin meningkat selaras dengan peningkatan kondisi perekonomian di Indonesia juga berarti adanya persaingan yang semakin ketat. Sebagian besar perusahaan memiliki tujuan yang sama yakni berorientasi untuk mendapatkan sejumlah laba semaksimal mungkin meskipun disamping misi-misi lainnya Khusnul (2016). Dengan melihat peluang dan kontribusi serta kenyataan yang ada peran UMKM terhadap perekonomian, maka maka dipandang perlu adanya grand strategy pengembangan melalui pemberdayaan UMKM yang menjadi sumber pertumbuhan baru perekonomian Indonesia, dalam hal dapat berperan dalam : (1). Mensejahterakan masyarakat, (2). Membuka lapangan pekerjaan, (3). Wahana pemerataan pembangunan untuk mengatasi kesenjangan pendapatan antar masyarakat, antar wilayah serta antara pedesaan dan perkotaan yang mempu mengurangi arus urbanisasi, (4). Pasar input dan output hasil-hasil produk UMKM, (5). Penghasil devisa, (6). Peningkatan pendapatan nasional (Renstra Kemenkop RI: 2012).

Prinsip keberlanjutan usaha menganggap bahwa badan usaha akan terus melakukan operasinya sepanjang proses penyelesaian proyek, perjanjian dan kegiatan yang sedang berlangsung. Prediksi keberlanjutan usaha suatu badan usaha sangat penting bagi manajemen dan pemilik badan usaha untuk mengantisipasi kemungkinan adannya potensi kebangkrutan, karena kebangkrutan menyangkut terjadinya biayabiaya baik biaya langsung maupun tidak langsung. Keberlanjutan usaha adalah sebuah kondisi disaat perusahaan memiliki kecukupan dana untuk menjalankan dan mengembangkan usaha

Berdasarkan pada permasalahan yang dihadapi oleh pelaku UMKM di Desa Banjasari Kecamatan Cerme Kabupaten Gresik maka tim melalui kemitraan antara akademisi dan pelaku UMKM melakukan penyulukan mengenai pengetahuan Analisis keberlanjutan Usaha Kecil dan Menengah Kegiatan ini dilakukan dengan harapan pelaku UMKM dapat menjalani New Normal Saat Pandemi Corona

\section{METODE PELAKSANAAN}

Persoalan yang dihadapi oleh mitra adalah kurangnya pengetahuan mengenai manajemen keuangan arus kas yang baik, sehingga tim memberikan solusi dengan memberikan penyuluhan. Metode pelaksanaan kegiatan pengabdian ini Antara lain :

1. Penyuluhan,

Metode penyuluhan yang dilakukan dalam kegiatan pengabdian ini adalah ceramah. Tim pengabdian memberikan pemahaman kepada mitra terkait dengan 
Analisis keberlanjutan Usaha Mikro Kecil dan Menengah menjalani New Normal Saat Pandemi Corona

2. Pendampingan,

Tahap kedua yang dilakukan oleh tim pengabdian yaitu pendampingan kepada mitra Desa Banjasari Kecamatan Cerme Kabupaten Gresik. Pendampingan dilakukan oleh tim pengabdian untuk mengetahui keberhasilan program yang ditawarkan oleh tim maka dilakukan diskusi antara tim dengan mitra. Hal ini dilakukan untuk mengetahui hambatan-hambatan yang dialami oleh mitra selama melakukan pencatatan keuangan sehingga tim dapat memberikan solusi kepada mitra.

3. Evaluasi Pelaksanaan,

Evaluasi dirancang dengan melakukan monitoring dengan pertemuan kembali pasca penyuluhan. Dalam monitoring ini akan didiskusikan tentang berbagai hal yang mereka alami pasca pelatihan. Berbagai masalah mungkin sekali muncul, dan pada saat itulah ditawarkan berbagai alternatif pemecahan.

\section{HASIL DAN PEMBAHASAN}

Hasil dalam kegiatan pengabdian ini adalah Kebijakan New Normal telah diterapkan berbagai dimensi kehidupan masyarakat yang harus di patuhisebagai pelaku usaha dapat melakukan pengelolaan Analisis keberlanjutan menjalani New Normal Saat Pandemi Corona, (Strategi Internal) 1.Mengubah Pola Bekerja menjadi Work from Home (WFH) dan Meminimalisir Interaksi Fisik dan Sosial :Mendesain/merencanakan ulang target mingguan dan pola pelaporan aktivitas bisnis, Mendefinisikan ulang core business UMKM 2.Bangun Komunikasi dengan Internal Stakeholders (Partner, Karyawan, Investor) Secara Berkala : Saling memberi perhatian dan semangat dengan menanyakan kondisi kesehatan, mental dan finansial, Berdiskusi dengan internal stakeholders (partner, karyawan, investor) tentang skenario bisnis terbaik di masa pandemi COVID-19, 3 Merencanakan Ulang Strategi Keuangan : Berfokus pada cash flow yang sehat diatara lain dengan cara menjual stok barang di inventory dengan diskon (semi cuci gudang) dan promosi lainnya, Pangkas anggaran yang dirasa tidak begitu penting di masa pandemic COVID-19 seperti anggaran BBM,Berfokus pada pendapatan internal stakeholders (partner, karyawan, investor), 4. Membuat Produk-Produk Baru/Tambahan yang Relevan dengan Kondisi Kebutuhan dan Perilaku Pasar di Masa COVID-19 dengan Menggunakan Sumber Kemampuan/Bahan Baku yang Telah Dimiliki untuk Mendapatkan Sumber Pendapatan Baru :Fashion: Menciptakan produk yang berkaitan dengan perlindungan keselamatan dan kesehatan diri. Contoh: Masker dengan desain unik, kacamata pelindung, Hijab dengan tambahan fitur masker, sarung tangan, hand sanitizer, disinfektan, dll., F\&B : Menciptakan produk makanan yang lebih tahan lama dan dikemas dengan desain menarik,Aplikasi Digital: Aplikasi sederhana yang mensolusikan berbagai permasalahan yang timbul di masa pandemi COVID-19. Contoh: aplikasi thermometer digital, aplikasi terlusur jejak perjalanan, 
aplikasi pengiriman logistik, dll.,5.Memindahkan Anggaran Pemasaran ke Online Channel, namun Tetap dengan Prinsip "Low Budget-High Impact" : Menggunakan iklan berbayar (Instagram, Facebook, Youtube, Google Adsense, e-commerce, dll), Menggunakan influencer berbayar yang relevan dengan produk yang ditawarkan.
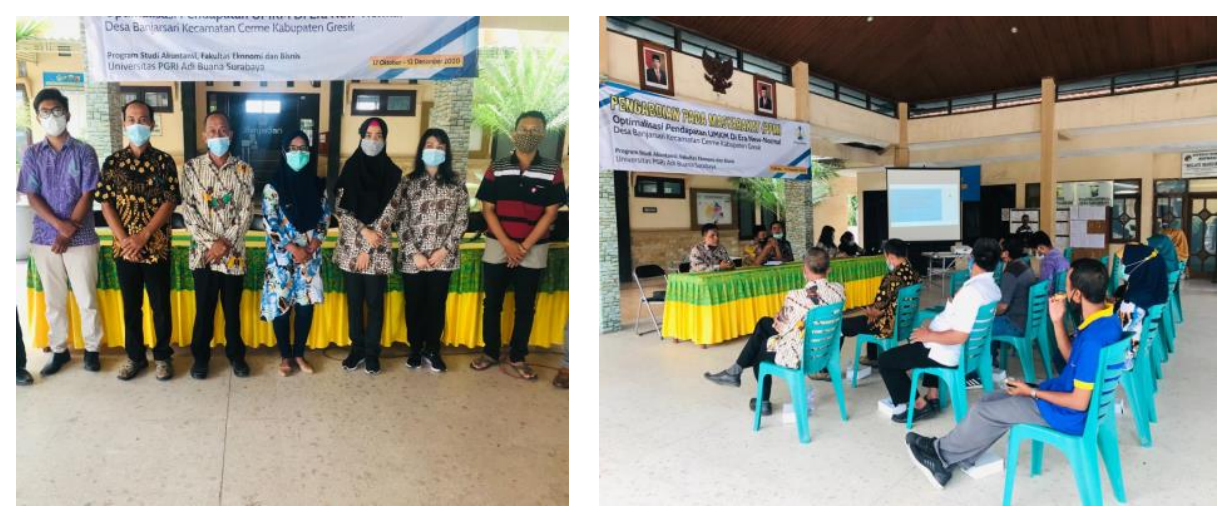

Gambar 1. Tim Penyuluhan Pengabdian Masyarakat

Strategi Eksternal, 1. Mengoptimalkan Omnichannel : Mengintegrasikan aktivitas bisnis pada website, aplikasi, media sosial, ecommerce, dan channel lain yang berpotensi,Membuat dan meningkatkan interaksi dengan konsumen melalui online channels.,Menciptakan konten bertemakan fun, social, berita/informasi dalam mendukung keselamatan dan kesehatan di masa pandemi COVID-19 seperti "Stay at home”, "Physical distancing”, dll, 2. Memberikan Informasi Penjaminan (assurance) dan Membuka Layanan Bantuan kepada Konsumen :Secara berkala menginformasikan jaminan kepada konsumen bahwa proses produksi dan delivery produk tersebut dilakukan secara aman sesuai protokol kesehatan COVID-19.3. Meningkatkan CoOpetition (cooperative in competition)/Kolaborasi dengan UMKM Lain: Menciptakan product bundling,Berkolaborasi dengan UMKM lain dalam menciptakan produk baru.4. Mengubah Model Pendapatan : Menjual sebanyak-banyaknya item produk dengan harga serendah mungkin untuk merangsang konsumen melakukan pembelian berulang pada transaksi-transaksi kecil.,Memberikan diskon, bonus, voucher dan service tambahan lainnya.,Menetapkan harga yang fleksibel tergantung jumlah permintaan (demand) dan waktu-waktu tertentu atau pemanfaatan momentum.

\section{SIMPULAN}

Setelah dilakukannya pelatihan dan pendampingan kepada pelaku usaha Desa Banjarsari Kecamatan Cerme Kabupaten Gresik, dapat disimpulkan bahwa mitra telah mampu Analisis keberlanjutan Usaha Kecil dan Menengah menjalani New Normal Saat Pandemi Corona. Adapun saran kegiatan ini adalah Pelaku UMKM dapat melakukan usahanya 


\section{UCAPAN TERIMA KASIH}

Tim pengabdian Fakultas Ekonomi Bisnis mengucapkan terima kasih atas pendanaan internal dari Lembaga Penelitian dan Pengabdian Masyarakat Universitas PGRI Adi Buana Surabaya yang telah diberikan kepada tim Pengabdian, sehingga program-program yang ditawarkan oleh tim kepada mitra berjalan dengan lancar serta mitra dapat memperoleh manfaat atas program yang ditawarkan yang dilakukan oleh tim pengabdian.

\section{DAFTAR PUSTAKA}

Kamenkop UKM Siapkan 5 Langkah Kebijakan atasi <asalah UMKM di Masa Pandemi(2020) http://www.depkop.go.id/read/kemenkop-ukm siapkan-5langkah-kebijakan-atasi-masalah-umkm-di-masa-pandemi diakses 08 Agustus 2020

Khusnul Khatimah Irwan, Thesis 2016, "Pengaruh Motivasi Berusaha Terhadap Keberlanjutan Usaha Kapal Phinisi di Kabupaten Bulukumba,Jurnal Riset wdisi IV, Vol 3, No. 002 (2016)

Kontribusi UMKM Naik https://www.kemenperin.go.id/artikel/14200/KontribusiUMKM-Naik diakses 08 Agustus 2020

Krisis ekonomi akibat Covid-19: IMF perkirakan 'luka ekonomi' karena krisis global akibat pandemi virus corona lebih buruk dari perkiraan www.bbc.com/indonesia/dunia-53168814 diakses 08 Agustus 2020

Rencana Strategis Kementrian Koperasi dan Usaha Kecil dan Menengah Repubilk IndonesiaTahun 2012-2014

Santi, Pramestika Era (2017) Analisis Keberlanjutan Usaha Pembuatan Pia di Kampung Pia" Warurejo, Pasuruan denganPendekatan

Dinamika Sistem. Sarjana thesis, Universitas Brawijaya

T Ariprabowo, MM Rachman, MA Miradji, SP Utomo (2020), Pendampingan Administrasi Dan Sistem Pencatatan Laporan Keuangan Sederhana Pada Pelaku Usaha Mikro Kecil Di Desa Pengulu Kecamatan Sidayu Kabupaten Gresik, Ekobis Abdimas 1/1/ Juni 2020

Vera Agustina Yanti, Siti Amanah2, Pudji Muldjono2, Pang Asngari Faktor yang mempengaruhi keberlanjutan usaha mikro kecil menengah di Bandung dan Bogor, Jurnal Pengkajian dan Pengembangan Teknologi Pertanian, Vol. 20, No.2, Juli 2018: 137-148 